\title{
Transgenic Crops: USDA Data on Small-Scale Tests Contribute Little to Commercial Risk Assessment
}

\author{
MARGARET MELLON \\ JANE RISSLER
}

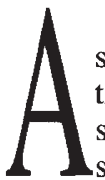

s transgenic crops near commercial production, the debate about their environmental safety is intensifying. Some argue that the safety of field trials predicts safety at the commercial scale. No one, however, has evaluated the data from the U.S. Department of Agriculture (USDA, Washington, D.C.) field trials to see whether they support the conclusion of safety. The Union of Concerned Scientists (UCS, Cambridge, MA) recently conducted such an evaluation and found that the data collected by the USDA have little value for commercial risk assessment.

The field tests. Developers of transgenic crop varieties routinely conduct 2-5 years of field tests to evaluate the performance of new products under field conditions. The tests are typically conducted under conditions that prevent movement of plants and pollen from the test site. Since 1987, The USDA has approved over 850 applications and notifications allowing over 2000 field test of transgenic plants. Twelve months after a test is initiated, the USDA requires that a report be submitted-containing information on methods of observation, resulting data, and analysis of deleterious effects on plants, nontarget organisms, or the environment.

As of May 26, 1994, the USDA had received 269 reports on field tests of transgenic crops. UCS requested the release of all the reports under the U.S. Freedom of Information Act (FOIA). Because of backlogs in processing FOIA requests, only 139 were available to the public. UCS selected the 85 most recent reports for analysis.

Weediness. None of the 85 reports mentioned experiments to assess weediness. Most $(86 \%)$ contained general observations about "volunteers," one manifestation of potential weediness. Typical statements included: "monitored for volunteers" and "no characteristics associated with weediness." Fourteen percent did not mention weediness at all.

Gene flow. Twenty-four reports concerned crops, including squash and canola, likely to interbreed with wild relatives in this country. Of these, 23 did not address gene flow impacts on wild relatives. Of the full set of 85 reports, $15 \%$ looked at movement of pollen, for example, into border or trap crops. One reported analysis of the formation of hybrids between a transgenic crop and a wild relative, a key experiment in evaluating gene flow. Seventy percent contained general observations concerning gene flow, such as "no evidence of transfer" and "no relatives with which the crop can cross." Fifteen percent did not mention gene flow.

New viruses. Viral components and infecting vi- ruses may interact in virus-resistant crops to produce new viral strains. Of the 19 reports concerning virus resistance, none contained experiments attempting to measure the production of new virus strains. Two addressed the risks in preliminary experiments by analyzing coat protein and nucleic acid levels. The other 17 reports did not mention the risks.

Nontarget effects. Fifteen reports concerned crops producing $B t$ toxin, an insecticidal protein from Bacillus thuringiensis. None even mentioned the likelihood of adverse impacts on nontarget insects.

Our analysis of the limited set of USDA field reports shows that many reports fail to even mention-much less measure-environmental risks. Of those reports that allude to environmental risk, most have only visually scanned field plots looking for stray plants or isolated test crops from relatives.

Not that the tests are without value. Even gross observations like these would pick up runaway weeds or grossly misshapen or diseased plants. The lack of such observations is welcome confirmation that transgenics do not look or behave wildly differently from ordinary crops.

Beyond the obvious, however, the observations that "nothing happened" in these hundreds of tests do not say much. In many cases, adverse impacts are subtle and would almost never be registered by scanning a field. In other cases, failure to observe evidence for the risks results from the contained conditions of the tests. For example, test crops are routinely isolated from wild relatives, a situation that guarantees that no outcrossing will be observed. But in order for the "nothing happened" to translate to a conclusion of safety in commercial use, test conditions must approximate ordinary production conditions - conditions in which weeds and viruses could emerge and gene flow could occur.

Designing meaningful tests is a challenge. It should be noted that the 2-5 years already required for efficacy tests provide ample opportunity for fruitful risk evaluation. We believe that tests should be done, and have offered a tiered testing protocol that is not unduly burdensome to industry (Rissler, J. and Mellon, M. 1991. Perils Amidst the Promise: Ecological Risks of Transgenic Crops in a Global Market. UCS, Cambridge, MA). Whether ours or another system is more suitable is a matter for another debate. Our point here is that care should be taken in citing the field test record as strong evidence for the safety of genetically engineered crops. It is not. Unless they are redesigned to collect environmental data, the field tests do not provide a track record of safety, but a case of "don't look, don't find." III
Margaret Mellon is director of the Agriculture and Biotechnology Program and Jane Rissler is senior staff scientist at the Union of Concerned Scientists, $1616 P$ St., N.W., Washington, D.C. 20036 (e-mail: ucsdc@igc.apc.org). 